Article

\title{
Expression of Resistance in Amaranthus spp. (Caryophyllales: Amaranthaceae): Effects of Selected Accessions on the Behaviour and Biology of the Amaranth Leaf-Webber, Spoladea recurvalis (Lepidoptera: Crambidae)
}

\author{
Stephen T. O. Othim ${ }^{1,2} \mathbb{E}^{\mathbb{C}}$, Srinivasan Ramasamy ${ }^{3}{ }^{(\mathbb{0})}$, Ruth Kahuthia-Gathu ${ }^{1}$, Thomas Dubois ${ }^{4}$, \\ Sunday Ekesi ${ }^{2}$ and Komi K. M. Fiaboe ${ }^{2, *}$ (i) \\ 1 Kenyatta University, School of Agriculture and Enterprise Development, \\ P.O. Box 43844-00100, Nairobi, Kenya; somburo@icipe.org (S.T.O.O.); rkahuthia@gmail.com (R.K.-G.) \\ 2 International Centre of Insect Physiology and Ecology (ICIPE), Plant Health Unit, \\ P.O. Box 30772-00100, Nairobi, Kenya; sekesi@icipe.org \\ 3 World Vegetable Center, P.O. Box 42, Shanhua, Tainan 74199, Taiwan; srini.ramasamy@worldveg.org \\ 4 World Vegetable Center, Eastern and Southern Africa, P.O. Box 10, Duluti, Arusha, Tanzania; \\ thomas.dubois@worldveg.org \\ * Correspondence: kfiaboe@icipe.org; Tel.: +254-(20)-863-2148
}

Received: 16 April 2018; Accepted: 6 June 2018; Published: 8 June 2018

check for updates

\begin{abstract}
Spoladea recurvalis F. is a major pest moth of amaranth (Amaranthus spp.) flowers worldwide, with a potential of causing complete foliage loss under severe outbreaks. Chemical insecticides are uneconomical for resource-poor farmers and pose health and environmental risks. Host plant resistance (HPR) to insects is an effective, economical and environmentally friendly alternative that is poorly understood and largely unexploited among traditional leafy vegetables. A total of 35 amaranth accessions were evaluated for the expression of their antixenotic and antibiotic traits against $S$. recurvalis, focusing on their effects on the biology of the pest in comparison with a susceptible accession. The accession VI036227 was found to be highly resistant against the pest, exhibiting exemplary antibiosis by causing $100 \%$ larval mortality within the first $36 \mathrm{~h}$, despite not being deterrent for oviposition. The accessions VI048076, VI056563 and VI047555-B demonstrated moderate resistance against the pest for specific parameters including low oviposition, moderate early stage larval mortality and reduced adult longevity. Total mortality and weight gain in these three accessions were, however, not significantly different from the susceptible control. Higher numbers of eggs were laid in no-choice compared to choice situations. The implications of these findings in the management of $S$. recurvalis on amaranths are discussed.
\end{abstract}

Keywords: antibiosis; antixenosis; IPM; longevity; mortality

\section{Introduction}

Amaranth plants, in the genus Amaranthus L. and family Amaranthaceae, are traditional leafy vegetables (TLVs) that are largely consumed in several countries around the world, not only as vegetables (leaves) but also as grains [1,2]. Amaranth foliage has gained widespread acceptance and popularity as a dietary constituent in Africa and Asia [3,4], mainly due to increased awareness of its nutritive and medicinal value as it is rich in vitamins A, B and C, calcium, iron, potassium, ascorbic acid and also provides an alternative source of vegetable protein $[1,3,5-8]$. The grains are equally nutritious and are largely used in feeding children and the elderly to boost their immunity by 
supplying much-needed micronutrients and as a major source of relief for the lactose-intolerant [1,9]. In addition to nutrition, amaranth also possesses qualities such as earliness to mature, palatability and adaptability to a broad range of climatic conditions, including temperature, moisture and water stress, assisted by its $C_{4}$ photosynthetic pathway [1]. Most amaranth species have also been shown to tolerate moderate salinity levels [10].

Arthropod pests and diseases present a major challenge to optimum productivity of amaranths in several regions of the world including Africa [11-14], Asia [15] and the Americas [7,16,17]. Currently, more than 250 species of insect pests have been reported to feed on amaranth worldwide, with a majority (50\%) falling in the category of leaf chewers/defoliators [11,16-18].

In Africa and Asia, the Hawaiian beet webworm/amaranth leaf-webber, Spoladea recurvalis (Fabricius, 1775) (Lepidoptera: Crambidae), has often been reported to be a major pest in amaranth fields, with a potential of causing complete defoliation of foliage under severe outbreaks [11,19-22]. The eggs of $S$. recurvalis are normally laid on the lower surface of leaves adjacent to leaf veins, from where they hatch and begin to feed on the crop [23]. Young larvae of S. recurvalis feed beneath the leaves only on the epidermis, skeletonising the tissues and occasionally spinning light webs in which they rest [4]. After the second instar, they skeletonise the foliage, leaving only the main veins intact, roll the leaves into distinctive leaf shelters, form webbing on leaves and leave frass on the leaves $[4,12,24]$. The webbing and rolling of the leaves severely diminishes the photosynthetic capacity and often leads to the death of the plant.

In several countries, management of this pest has been through the use of synthetic insecticides [11,16,25]. However, insecticide application to control vegetable arthropod pests is not economical under subsistence farming, being largely beyond the means of resource-poor farmers; it also induces resistance in pests and is often inefficient [26-28]. Amaranth, being a short season crop, poses the inevitable temptation of farmers using the chemicals indiscriminately and non-judiciously, leading to environmental pollution and elimination of natural enemies [28]. Moreover, health concerns due to residue levels in vegetables have often been raised concerning these pesticides, thus the need for development of effective, safe and sustainable Integrated Pest Management (IPM) approaches [25,26,28]. The moth attractant phenylacetaldehyde (PAA), which has been demonstrated to be effective in capturing $S$. recurvalis in Hawaii, was not effective in capturing the East African populations [21,22,29].

In light of these developments in the management of $S$. recurvalis, host plant resistance (HPR), though greatly unexploited among TLVs, assumes a pivotal role in the management of pests of amaranth, particularly $S$. recurvalis. Studies have shown that different varieties, accessions or lines of amaranth exhibit different levels of resistance in terms of herbivory and infestation by pests including S. recurvalis in open field conditions $[7,30]$. The mechanisms of such resistance in amaranths are, however, still unknown. This study therefore sought to unravel the mechanisms of resistance with a special focus on expression of antixenosis and antibiosis against $S$. recurvalis among selected resistant accessions of amaranth.

\section{Materials and Methods}

\subsection{Amaranth Accessions}

Open field experiments were conducted in 2016 and 2017 to screen 31 amaranth accessions obtained from the World Vegetable Center (WorldVeg) gene bank in Taiwan and four improved lines from WorldVeg Eastern and Southern Africa (ESA) for resistance against leaf-webbers [30]. In this study, we conducted a further screening for expression of resistance in a screenhouse on all 35 test accessions and lines (hereafter both called accessions) and one susceptible accession in choice assays. Morphological characteristics of the amaranth accessions tested are presented in Table 1. From both the open field assay previously conducted by Othim et al. [30] and the screenhouse assays conducted in this study, eight amaranth accessions exhibiting pest resistance and the susceptible accession were selected on the basis of damage incidence and severity, pest incidence and abundance and 
oviposition preference for in-depth assessment of their effects on selected biological traits of the pest. The susceptible accession was considered as such because it had the most severe damage and the highest pest incidence and abundance. The selected accessions were grown in the screenhouse at the WorldVeg facility in Arusha. The seeds were sown in plastic trays containing a substrate of soil and manure in the ratio 4:1. Two to three weeks after germination, the seedlings were transplanted into plastic pots of $10 \mathrm{~cm}$ diameter $\left(1000 \mathrm{~cm}^{3}\right)$ and maintained with regular watering for use in the experiments. For pest colony maintenance, Amaranthus dubius Mart. ex Thell. (Ex-zan), obtained from WorldVeg's ESA genebank in Arusha, Tanzania, was used.

\subsection{Amaranth Leaf-Webber (Spoladea recurvalis F.) Colony}

A colony of the amaranth leaf-webber was established and maintained in the entomology laboratory at WorldVeg, Arusha on A. dubius for five generations prior to their experimental use. The adults and larvae of $S$. recurvalis were originally collected from amaranth fields within WorldVeg $\left(3.38^{\circ} \mathrm{S}, 36.8^{\circ} \mathrm{E}\right)$ in November and December 2015. Adult moths were placed in transparent Perspex cages $(40 \times 40 \times 45 \mathrm{~cm})$ with a sliding door and a netting material at the back and on the sides for ventilation. The moths were fed on $10 \%$ honey solution soaked in cotton wool and provided with potted amaranth plants for oviposition. The plants were replaced every $24 \mathrm{~h}$ and placed in separate holding cages $(50 \times 50 \times 60 \mathrm{~cm})$ made from transparent Perspex material with netting at the back and on the sides for the eggs to hatch. Newly hatched larvae were left to feed on the live plants for three to four days and then transferred into plastic containers $(15 \times 7 \times 5 \mathrm{~cm})$ lined with paper towel and fine netting material on the lid for ventilation. Fresh amaranth leaves were supplied to the larvae daily for food until pupation. The pupae were incubated under similar conditions in the plastic containers until adult emergence. The laboratory conditions were maintained at $25 \pm 2{ }^{\circ} \mathrm{C}, 50-70 \% \mathrm{RH}$ and photoperiod of 12:12 h (light:dark). 
Table 1. Amaranth accessions, lines developed by single plant selection from germplasm collections studied and some of their morphological characteristics.

\begin{tabular}{|c|c|c|c|c|c|c|c|c|c|c|}
\hline Gene Bank Code & Species & Type & Leaf Colour & Leaf Shape & $\begin{array}{l}\text { Country of } \\
\text { Origin }\end{array}$ & $\begin{array}{l}\text { Number of } \\
\text { Branches per } \\
\text { Plant (mean) }\end{array}$ & $\begin{array}{c}\text { Plant } \\
\text { Height } \\
(\text { mean) } \mathrm{cm}\end{array}$ & $\begin{array}{l}\text { Leaf Width } \\
\text { (mean) cm }\end{array}$ & $\begin{array}{l}\text { Leaf Length } \\
\text { (mean) cm }\end{array}$ & $\begin{array}{c}\text { Petiole } \\
\text { Length } \\
(\text { mean) } \mathrm{cm}\end{array}$ \\
\hline VI033482* & A. tricolor L. & Accession & Green & Reniform & Malaysia & 9.0 & 100.9 & 10.6 & 19.3 & 5.0 \\
\hline RVI00002 & A. cruentus L. & Line & Green & Ovate & Zambia & 12.5 & 122.6 & 6.6 & 16.5 & 10.2 \\
\hline RVI00005 & A. dubius Mart. & Line & $\begin{array}{l}\text { Light } \\
\text { reddish }\end{array}$ & Ovate & Tanzania & 12.2 & 140.3 & 6.0 & 12.5 & 7.6 \\
\hline RVI00027 & Amaranthus sp. 1 & Line & Green & Ovate & Malawi & 7.3 & 96.3 & 6.2 & 11.1 & 7.8 \\
\hline RVI00053 & A. dubius Mart. & Line & Green & Ovate & Uganda & 11.0 & 167.0 & 8.7 & 15.6 & 8.0 \\
\hline VI033477 & Amaranthus sp. 2 & Accession & Reddish & Ovate & Malaysia & 9.2 & 99.7 & 7.9 & 12.3 & 5.2 \\
\hline VI033479 & Amaranthus sp. 3 & Accession & Green & Ovate & Malaysia & 11.3 & 100.8 & 4.9 & 7.6 & 4.2 \\
\hline VI033487 & A. cruentus L. & Accession & Green & Reniform & Malaysia & 13.5 & 128.7 & 5.6 & 7.7 & 6.6 \\
\hline VI036225 & A. graecizans $\mathrm{L}$. & Accession & Green & Ovate & Hungary & 15.4 & 77.2 & 1.6 & 3.2 & 2.3 \\
\hline VI036227 & A. blitoides Watson & Accession & Green & Oblanceolate & Hungary & 15.8 & 67.4 & 1.2 & 3.2 & 1.6 \\
\hline VI044367 & A. cruentus L. & Accession & Green & Lanceolate & Tanzania & 9.1 & 123.5 & 5.8 & 13.7 & 10.2 \\
\hline VI044369 & A. hypochondriacus L. & Accession & Green & Lanceolate & Ghana & 13.7 & 129.0 & 6.1 & 17.0 & 9.2 \\
\hline VI044388 & A. graecizans $\mathrm{L}$. & Accession & Green & Oblanceolate & India & 14.6 & 89.8 & 2.3 & 4.3 & 2.5 \\
\hline VI044432 & A. viridis $\mathrm{L}$. & Accession & Green & Cordate & Indonesia & 11.0 & 102.9 & 4.5 & 6.9 & 4.0 \\
\hline VI044437-A & A. cruentus $\mathrm{L}$. & Accession & Green & Lanceolate & Malaysia & 11.5 & 89.5 & 5.5 & 13.0 & 7.2 \\
\hline VI044473 & A. palmeri Watson & Accession & Green & Obovate & Senegal & 9.0 & 80.1 & 2.2 & 4.4 & 2.4 \\
\hline VI046233-A & Amaranthus sp. 4 & Accession & Reddish & Lanceolate & Vietnam & 8.0 & 142.1 & 6.8 & 17.0 & 10.6 \\
\hline VI047517-B & A. tricolor $\mathrm{L}$. & Accession & Green & Ovate & Bangladesh & 12.9 & 119.8 & 8.1 & 15.9 & 7.7 \\
\hline VI047555-B & A. tricolor $\mathrm{L}$. & Accession & Green & Lanceolate & Vietnam & 10.9 & 135.6 & 4.5 & 13.4 & 4.8 \\
\hline VI048076 & A. tricolor $\mathrm{L}$. & Accession & Green & Cordate & Bangladesh & 13.1 & 130.1 & 8.0 & 13.5 & 7.1 \\
\hline VI048864-A & A. viridis $\mathrm{L}$. & Accession & Green & Cordate & Thailand & 10.2 & 95.1 & 4.1 & 5.8 & 3.6 \\
\hline VI048919 & Amaranthus sp. 5 & Accession & Green & Ovate & Thailand & 11.6 & 126.1 & 3.7 & 7.0 & 4.3 \\
\hline VI049242 & Amaranthus sp. 6 & Accession & Green & Ovate & Thailand & 11.6 & 87.8 & 4.4 & 5.8 & 3.7 \\
\hline VI049502 & Amaranthus sp. 7 & Accession & Green & Cordate & Thailand & 10.0 & 103.1 & 4.7 & 6.8 & 4.1 \\
\hline VI049504 & Amaranthus sp. 8 & Accession & Green & Lanceolate & Thailand & 12.1 & 134.2 & 3.0 & 6.6 & 3.2 \\
\hline VI049530 & Amaranthus sp. 9 & Accession & Green & Ovate & Thailand & 10.4 & 89.2 & 4.3 & 6.4 & 3.9 \\
\hline VI049639 & A. viridis L. & Accession & Green & Ovate & Thailand & 11.3 & 91.7 & 4.2 & 6.1 & 3.5 \\
\hline VI049698 & A. viridis $\mathrm{L}$. & Accession & Green & Ovate & Thailand & 12.4 & 100.5 & 3.9 & 5.5 & 3.4 \\
\hline VI050609-A & A. tricolor $\mathrm{L}$. & Accession & Variegated & Cordate & Vietnam & 9.8 & 129.1 & 9.2 & 11.7 & 6.8 \\
\hline VI050609-B & A. tricolor $\mathrm{L}$ & Accession & Variegated & Ovate & Vietnam & 8.5 & 140.9 & 9.6 & 15.0 & 6.1 \\
\hline VI054569 & A. gracilis Desf. & Accession & Green & Ovate & Philippines & 11.0 & 95.1 & 4.5 & 7.2 & 3.9 \\
\hline VI054798 & Amaranthus sp. 10 & Accession & Green & Ovate & Lao PDR & 12.4 & 89.3 & 4.1 & 6.2 & 3.3 \\
\hline
\end{tabular}


Table 1. Cont

\begin{tabular}{|c|c|c|c|c|c|c|c|c|c|c|}
\hline Gene Bank Code & Species & Type & Leaf Colour & Leaf Shape & $\begin{array}{l}\text { Country of } \\
\text { Origin }\end{array}$ & $\begin{array}{l}\text { Number of } \\
\text { Branches per } \\
\text { Plant (mean) }\end{array}$ & $\begin{array}{c}\text { Plant } \\
\text { Height } \\
\text { (mean) cm }\end{array}$ & $\begin{array}{l}\text { Leaf Width } \\
\text { (mean) } \mathrm{cm}\end{array}$ & $\begin{array}{l}\text { Leaf Length } \\
\text { (mean) cm }\end{array}$ & $\begin{array}{c}\text { Petiole } \\
\text { Length } \\
\text { (mean) } \mathrm{cm}\end{array}$ \\
\hline VI055127 & A. viridis $\mathrm{L}$. & Accession & Green & Ovate & Malaysia & 11.4 & 108.1 & 5.6 & 10.3 & 6.6 \\
\hline VI055128 & A. viridis $\mathrm{L}$. & Accession & Green & Cordate & Malaysia & 10.7 & 123.4 & 5.0 & 7.0 & 3.9 \\
\hline VI055135 & A. viridis $\mathrm{L}$ & Accession & Green & Cordate & Malaysia & 10.8 & 92.0 & 5.0 & 7.2 & 4.1 \\
\hline VI056563 & Amaranthus sp. 11 & Accession & Reddish & Ovate & Bangladesh & 9.7 & 136.9 & 9.0 & 17.1 & 8.3 \\
\hline Mean & & & & & & 11.2 & 110.7 & 5.5 & 10.0 & 5.5 \\
\hline$p$-value & & & & & & 0.053 & $<0.001$ & $<0.001$ & $<0.001$ & $<0.001$ \\
\hline LSD (5\%) & & & & & & 4.38 & 26.74 & 1.4 & 3.69 & 2.33 \\
\hline
\end{tabular}

* Susceptible check. 


\subsection{Choice Bioassay}

Choice assays were conducted in two sets since all the 36 accessions could not fit in a single cage. The experiment was conducted within a screen-house in a split plot design replicated six times. In the first set (set-up A), 17 test accessions and the susceptible accession were exposed to 25 mated female adults of $S$. recurvalis in a glass cage measuring $150 \times 100 \times 120 \mathrm{~cm}$. In the second set (set-up B), established three weeks later, the 18 remaining test accessions and the susceptible accession were exposed to 25 mated female adults of $S$. recurvalis in the same glass cages used for the first set. One potted plant of each accession (seven weeks old) was randomly placed in each cage and left for $48 \mathrm{~h}$ for the moths to lay eggs. The plants were watered after $24 \mathrm{~h}$ and the moths were provided with $10 \%$ honey solution on cotton plugs to feed. The plants were then removed from the cages and the leaves of each plant thoroughly inspected for the presence of eggs, which were counted with the aid of a dissecting microscope and recorded.

\subsection{No-Choice Bioassay}

The eight most resistant accessions identified from the field experiments conducted by Othim et al. [30] and the choice experiments above were assessed individually in a no-choice experiment in comparison with the susceptible accession. One potted amaranth plant of each selected accession at six to seven weeks of age was exposed to two mated female moths of $S$. recurvalis from the stock culture for $48 \mathrm{~h}$ in the transparent Perspex cages. During the exposure period, S. recurvalis adults were fed on $10 \%$ honey solution soaked in cotton wool and the plants were watered adequately. After $48 \mathrm{~h}$ of exposure, the plants were removed from the cages and the leaves were inspected for the presence of eggs under a dissecting microscope. The number of eggs on each amaranth accession was recorded. This experiment was replicated six times with each accession.

\subsection{Effect of Accession on Weight Gain of Amaranth Leaf-Webber}

One or two leaves (based on leaf size) from each of the eight selected amaranth accessions and the susceptible accession were exposed to one larva of $S$. recurvalis for $48 \mathrm{~h}$ in a petri dish lined with moistened filter paper. The leaves were obtained from amaranth accessions grown and maintained in the screen-house at six to seven weeks. The larvae were obtained from the laboratory stock culture and exposed at 3-5 days old to each accession. Prior to their exposure in the experiment, the larvae were deprived of food for $12 \mathrm{~h}$. The weight of each larva was measured before and after $48 \mathrm{~h}$ of exposure to the leaves using a digital scale (Mettler AE200 analytical balance, Columbus, OH, USA). This experiment was replicated 12 times with each amaranth accession. The weight gain and percentage weight gain by $S$. recurvalis larvae on each accession were then calculated.

\subsection{Effects of Selected Amaranth Accessions on the Development of Amaranth Leaf-Webber and Adult Longevity}

The nine accessions tested in no-choice experiment were evaluated for their effect on larval development. Five neonate larvae of $S$. recurvalis were placed in a plastic Petri dish $(8 \mathrm{~cm}$ diameter) lined with filter paper to absorb excess moisture. These were supplied daily with fresh leaves of the selected accessions until all larvae had pupated or died. The pupae were then incubated under the same conditions until adult emergence. The emerged adults were placed in Perspex cages and fed on $10 \%$ honey solution until they died. The assay was replicated 10 times with each selected amaranth accession. The data on larval, pupal and total developmental times, larval and pupal mortalities and adult longevity were collected for each accession. Early stage larval mortality was recorded as mortality within the first $36 \mathrm{~h}$ (when the larvae are not causing considerable damage) of exposure.

\subsection{Data Analysis}

One-way analysis of variance (ANOVA) was used to compare morphological characteristics of amaranth accessions including number of branches per plant, plant height, leaf length and width 
and petiole length using GENSTAT version 19.1. All other statistical analyses were performed using R-Software version 3.4.0 (R Core Team, 2017). The count data were analysed using generalized linear model (GLM) with $\log _{10}$-link and Poisson distribution error to compare the factors: number of eggs oviposited by female $S$. recurvalis moths from both choice and no-choice assays, number of days taken for larval, pupal and total development by $S$. recurvalis and adult longevity on various accessions. The effect of a factor for a GLM is reflected in the deviance (likelihood ratio test statistic) that has an appropriate chi-square distribution; hence the chi-square values are presented as test statistics. The "Relative Risk/Risk Ratio" (RR), which is a ratio of the probability of having the pest lay an egg on the test amaranth accession relative to the susceptible accession, was calculated as an exponent of the coefficients obtained from the Poisson regressions. The number of eggs obtained in the choice and no-choice assays was compared using a chi-square goodness-of-fit test. The percentage weight gain and weight gain $(\mathrm{mg})$ by larvae of $S$. recurvalis, larval and pupal mortalities, egg viability, fecundity and $F_{1}$ female proportions were analysed using one-way ANOVA. The percentage weight gains by larvae of $S$. recurvalis and larval and pupal mortalities were square-root transformed before ANOVA, and Tukey's test used to separate means where significant differences occurred. The instantaneous rate of increase $\left(r_{i}\right)$ was calculated according to Stark and Banks [31] using the following equation:

$$
r_{i}=\ln \left(\mathrm{N}_{\mathrm{f}} / \mathrm{N}_{\mathrm{o}}\right) / \mathrm{T}
$$

where $N_{f}$ is the final number of insects, $N_{o}$ is the initial number of insects, and $T$ is the change in time (number of days the experiment was run). Positive values of $r_{i}$ indicate a growing population, $r_{i}=0$ indicates a stable population, and negative $r_{i}$ values indicate a population in decline and headed toward extinction. Spearman's rank order correlation analysis was conducted to establish the existence of relationships between larval vs. pupal mortalities and larval mortality vs. time taken before mortality in S. recurvalis.

\section{Results}

\subsection{Morphological Characteristics of Amaranth Accessions}

Amaranth accessions exhibited different morphological characteristics including leaf coloration, leaf shape, leaf size and growth habit among others. The susceptible accession had significantly broader $(F=37.9 ; \mathrm{df}=35,178 ; p<0.001)$ and longer $(F=31.1 ; \mathrm{df}=35,178 ; p<0.001)$ leaves compared to the resistant accessions (Table 1). The smallest leaf sizes were recorded on accession VI036227 with width of $1.2 \pm 0.1 \mathrm{~cm}$ and length $3.2 \pm 0.7 \mathrm{~cm}$ compared to $10.6 \pm 0.6$ and $19.3 \pm 2.2 \mathrm{~cm}$ in the susceptible accession. The plant height and petiole lengths also differed significantly among the amaranth accessions. There was no significant difference in the number of branches across all the accessions. Leaf coloration and shape also varied among the accessions with accessions VI046233-A, VI033477 and VI056563 possessing red leaves compared to the green leaves in the susceptible accession (Table 1).

\subsection{Oviposition by S. recurvalis in Choice Situation}

In oviposition choice assays, there were significant differences in the number of eggs oviposited on the tested accessions in set-up A $\left(\chi^{2}=284.03 ; \mathrm{df}=17,85 ; p<0.001\right)$ and set-up B $\left(\chi^{2}=1056.40\right.$; $\mathrm{df}=18,93 ; p<0.001$ ) (Table 2 ). In set-up $A$, the susceptible accession had significantly higher number of eggs compared to all the other 17 accessions. The fewest eggs were recorded on accessions VI044432 and VI054569, which had a relative risk (RR) of 0.06 compared to the susceptible accession. In set-up B, the accession VI048919 $(R R=1.39)$ recorded significantly higher number of eggs compared to the susceptible accession while accession VI050609-B $(R R=1.20)$ did not differ significantly from the susceptible accession in the number of eggs laid by S. recurvalis (Table 2). The remaining 16 accessions had significantly lower number of eggs compared to the susceptible accession. The average number of eggs laid by S. recurvalis across all the accessions in both set-up A and B was $7.80 \pm 0.85$ and 
ranged between $1.50 \pm 0.56$ in the least preferred accession to $40.20 \pm 16.41$ in the most preferred accession (Table 2).

Table 2. Number of eggs (mean \pm SE) laid by S. recurvalis on different accessions of amaranth in the choice assays in set-up A and B.

\begin{tabular}{cccccc}
\hline \multicolumn{2}{c}{ Set-up A } & & \multicolumn{3}{c}{ Set-up B } \\
\hline Gene Bank Code & Number of Eggs & Relative Risk & Gene Bank Code & Number of Eggs & Relative Risk \\
\hline VI033482* & $25.67 \pm 7.62 \mathrm{a}$ & & VI033482* & $29.00 \pm 7.95 \mathrm{~b}$ & \\
VI033487 & $11.33 \pm 4.57 \mathrm{~b}$ & 0.44 & VI048919 & $40.20 \pm 16.41 \mathrm{a}$ & 1.39 \\
VI044388 & $10.00 \pm 2.92 \mathrm{bc}$ & 0.39 & VI050609-B & $34.67 \pm 9.47 \mathrm{ab}$ & 1.2 \\
VI036227 & $8.83 \pm 3.93 \mathrm{bcd}$ & 0.34 & VI033477 & $15.00 \pm 4.87 \mathrm{c}$ & 0.52 \\
RVI00027 & $7.33 \pm 2.85 \mathrm{be}$ & 0.29 & VI049504 & $11.40 \pm 6.21 \mathrm{~cd}$ & 0.39 \\
RVI00005 & $6.17 \pm 2.30 \mathrm{cf}$ & 0.24 & VI047517-B & $9.83 \pm 4.48 \mathrm{cde}$ & 0.34 \\
VI048076 & $6.17 \pm 1.64 \mathrm{cf}$ & 0.24 & VI056563 & $9.83 \pm 3.51 \mathrm{cde}$ & 0.34 \\
VI049639 & $4.33 \pm 1.74 \mathrm{def}$ & 0.17 & VI055127 & $6.00 \pm 3.04 \mathrm{def}$ & 0.21 \\
RVI00002 & $4.00 \pm 2.08 \mathrm{ef}$ & 0.16 & VI046233-A & $6.17 \pm 3.82 \mathrm{def}$ & 0.21 \\
RVI00053 & $3.83 \pm 1.70 \mathrm{ef}$ & 0.15 & VI049530 & $6.67 \pm 3.48 \mathrm{def}$ & 0.23 \\
VI036225 & $3.67 \pm 2.01 \mathrm{ef}$ & 0.14 & VI050609-A & $6.67 \pm 2.89 \mathrm{def}$ & 0.23 \\
VI044473 & $3.33 \pm 1.54 \mathrm{ef}$ & 0.13 & VI047555-B & $3.67 \pm 1.87 \mathrm{ef}$ & 0.13 \\
VI044369 & $3.20 \pm 2.03 \mathrm{ef}$ & 0.12 & VI055128 & $3.50 \pm 2.05 \mathrm{ef}$ & 0.12 \\
VI044367 & $2.83 \pm 0.83 \mathrm{ef}$ & 0.11 & VI054798 & $2.83 \pm 2.46 \mathrm{f}$ & 0.1 \\
VI044437-A & $2.40 \pm 1.03 \mathrm{ef}$ & 0.09 & VI055135 & $2.50 \pm 0.92 \mathrm{f}$ & 0.09 \\
VI049698 & $2.33 \pm 0.56 \mathrm{f}$ & 0.09 & VI048864-A & $2.33 \pm 1.76 \mathrm{f}$ & 0.08 \\
VI044432 & $1.50 \pm 0.56 \mathrm{f}$ & 0.06 & VI033479 & $2.17 \pm 1.78 \mathrm{f}$ & 0.07 \\
VI054569 & $1.50 \pm 0.85 \mathrm{f}$ & 0.06 & VI049242 & $2.17 \pm 1.17 \mathrm{f}$ & 0.07 \\
& & VI049502 & $1.50 \pm 0.81 \mathrm{f}$ & 0.05
\end{tabular}

* Susceptible accession. Means followed by same lower-case letter within a column are not significantly different at $p<0.05$ (Tukey's test).

\subsection{Oviposition by S. recurvalis in No-Choice Condition}

In the no-choice test, where a total of eight accessions were compared to the susceptible one, $S$. recurvalis laid more eggs on the susceptible accession compared to all the other accessions $\left(\chi^{2}=192.75 ; \mathrm{df}=7,37 ; p<0.001\right)$ (Table 3). The accession VI048076 recorded the least number of eggs $(18.50 \pm 6.63)$ with a RR $=0.31$ compared to the susceptible accession and was also significantly lower than all the other seven accessions. The accessions VI044437-A ( RR =0.49), VI047555-B $(R R=0.49)$ and RVI00053 $(R R=0.50)$ also had fewer eggs compared to VI049698 $(R R=0.72)$. Accession VI036227 $(\mathrm{RR}=0.67)$ had a higher number of eggs compared to accessions VI048076 and VI044437-A, but did not differ significantly from accessions RVI00053, VI047555-B, VI049698 and VI056563 (Table 3). The number of eggs laid by $S$. recurvalis in the no-choice assay was significantly higher than those laid in the choice situation $\left(\chi^{2}=1305.10 ; \mathrm{df}=1 ; p<0.001\right)$.

Table 3. Number of eggs (mean \pm SE) laid on selected accessions in the no-choice and choice assays.

\begin{tabular}{|c|c|c|c|c|c|c|c|}
\hline Gene Bank Code & No Choice & Relative Risk & Choice & Relative Risk & $x^{2}$ & $\mathrm{df}$ & $p$ Value \\
\hline VI033482 * & $59.63 \pm 10.49 \mathrm{eA}$ & - & $\begin{array}{l}21.58 \pm \\
5.30 \mathrm{~dB}\end{array}$ & - & 127.96 & 1 & $<0.001$ \\
\hline RVI00053 & $30.00 \pm 6.52 \mathrm{bcA}$ & 0.50 & $\begin{array}{c}3.83 \pm \\
1.70 \mathrm{abB}\end{array}$ & 0.18 & 183.54 & 1 & $<0.001$ \\
\hline VI036227 & $40.20 \pm 10.24 \mathrm{cdA}$ & 0.67 & $\begin{array}{l}8.83 \pm \\
3.93 \mathrm{cB}\end{array}$ & 0.41 & 170.15 & 1 & $<0.001$ \\
\hline VI044437-A & $29.33 \pm 10.24 \mathrm{bA}$ & 0.49 & $\begin{array}{c}2.40 \pm \\
1.03 \mathrm{abB}\end{array}$ & 0.11 & 282.65 & 1 & $<0.001$ \\
\hline VI047555-B & $29.40 \pm 10.27 \mathrm{bcA}$ & 0.49 & $\begin{array}{c}3.67 \pm \\
1.87 \mathrm{abB}\end{array}$ & 0.17 & 181.96 & 1 & $<0.001$ \\
\hline VI048076 & $18.50 \pm 6.63 \mathrm{aA}$ & 0.31 & $\begin{array}{c}6.17 \pm \\
1.64 \mathrm{bcB}\end{array}$ & 0.29 & 72.01 & 1 & $<0.001$ \\
\hline VI049698 & $42.80 \pm 18.14 \mathrm{dA}$ & 0.72 & $\begin{array}{l}2.33 \pm \\
0.56 \mathrm{aB}\end{array}$ & 0.11 & 347.38 & 1 & $<0.001$ \\
\hline VI056563 & $37.20 \pm 5.54 \mathrm{bcdA}$ & 0.62 & $\begin{array}{l}9.83 \pm \\
3.51 \mathrm{cB}\end{array}$ & 0.46 & 129.6 & 1 & $<0.001$ \\
\hline & $\begin{array}{c}\chi^{2}=192.75 \\
\mathrm{df}=7,37 \\
p<0.001\end{array}$ & & $\begin{array}{c}\chi^{2}=281.29 \\
\mathrm{df}=7,45 \\
p<0.001\end{array}$ & & & & \\
\hline
\end{tabular}

* Susceptible accession. Means followed by the upper-case letters within rows or lower-case letter within columns are not significantly different at $p<0.05$ using Tukey's test (chi-square test). 


\subsection{Weight Gain by Larvae of S. recurvalis after 48 h of Feeding on the Selected Amaranth Accessions}

The weight gained $(\mathrm{mg})$ by larvae of $S$. recurvalis after feeding on the eight selected amaranth accessions for $48 \mathrm{~h}$ differed significantly $(F=6.13$; $\mathrm{df}=8,99 ; p<0.001)$ with accession VI036227 producing the lowest weight gain. Accessions RVI00053, VI033479, VI044437-A, VI047555-B, VI049698 and VI056563 did not differ significantly from the susceptible accession in the weight gain but were significantly higher than accession VI036227 (Figure 1). The average weight gain and percentage weight gain by S. recurvalis was $8.11 \pm 0.68 \mathrm{mg}$ and $181.0 \pm 14.86 \%$, respectively (Figure 1 ).

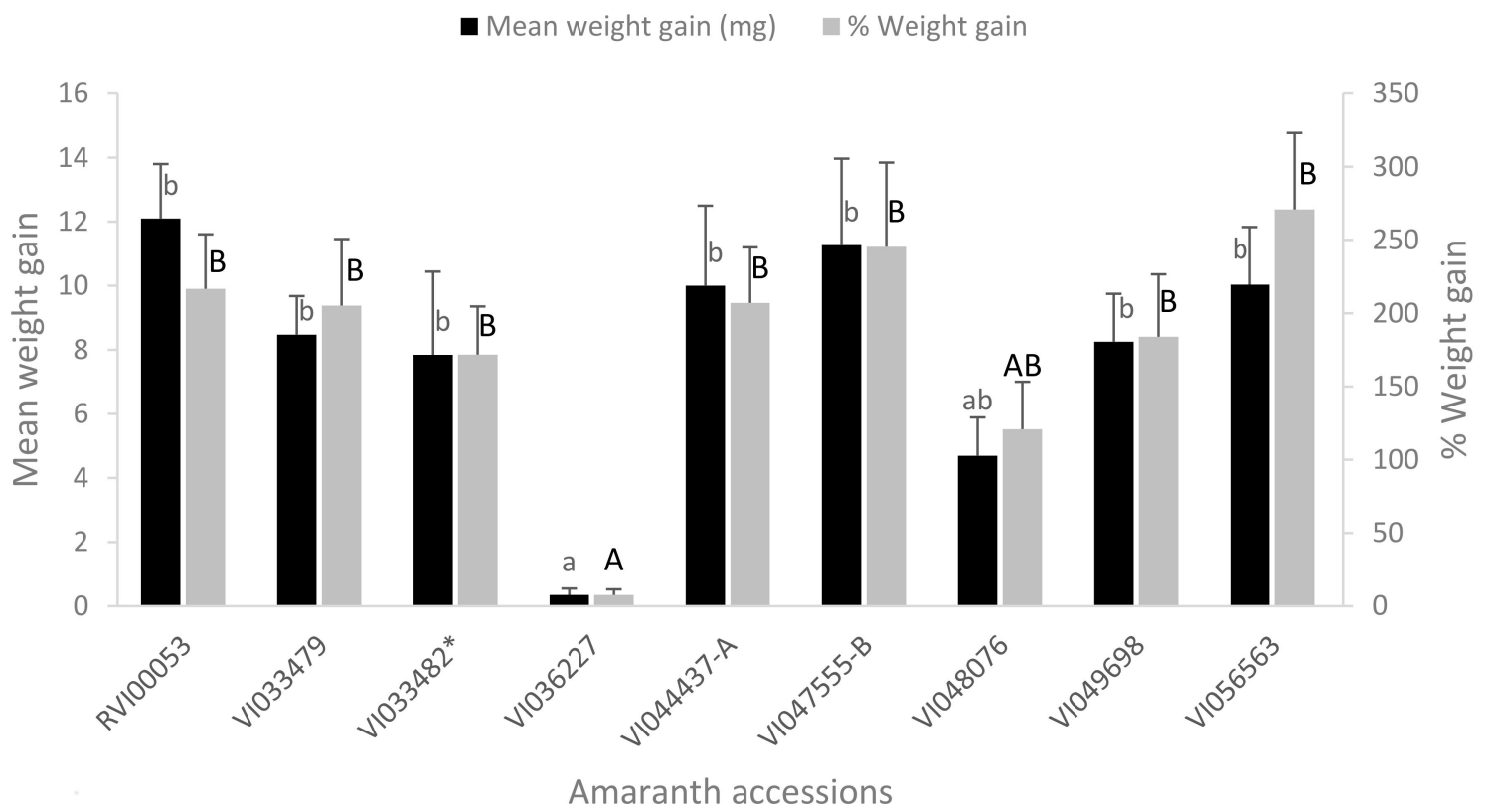

Figure 1. Weight gain $(\mathrm{mg})$ and percentage weight gain (mean $\pm \mathrm{SE}$ ) by larvae of $S$. recurvalis when fed on different amaranth accessions for $48 \mathrm{~h}$. (Mean weight gain (\% weight gain) with the same lower (upper) case alphabet is not significantly different at $p<0.05$, (Tukey's test)). ${ }^{*}$ Susceptible accession.

\subsection{Development Time of S. recurvalis on the Selected Amaranth Accessions}

The average larval development time was $13.5 \pm 0.12$ days across the eight selected accessions and ranged between $13.23 \pm 0.3$ and $14.0 \pm 0.56$ days on VI049698 and VI056563, respectively. Larval development on accession VI036227 did not advance beyond two days of exposure to the accession and hence larval development on this accession could not be determined. When presented with leaves from accession VI026227, the larvae of S. recurvalis gnawed only a small portion of the leaf and in some cases did not even attempt to feed on the leaves. There were no significant differences in the larval $\left(\chi^{2}=1.07 ; \mathrm{df}=7,228 ; p=0.994\right)$, pupal $\left(\chi^{2}=3.35 ; \mathrm{df}=7,112 ; p=0.851\right)$, and total $\left(\chi^{2}=1.04 ; \mathrm{df}=7,112 ;\right.$ $p=0.994$ ) development times of $S$. recurvalis across the tested accessions (Table 4 ). The mean pupal development time across all the accessions was $6.36 \pm 0.13$ days and ranged between $5.86 \pm 0.17$ and $7.45 \pm 0.69$ days on VI044437-A and VI033482, respectively. The mean total development time of $S$. recurvalis was $19.09 \pm 0.15$ days across the tested accessions, ranging between $18.60 \pm 0.45$ and $20.0 \pm 0.80$ days. 
Table 4. Larval, pupal and total developmental times (mean \pm SE) (days) of S. recurvalis on selected amaranth accessions and early stage $(36 \mathrm{~h})$ larval mortality on each accession.

\begin{tabular}{|c|c|c|c|c|}
\hline Gene Bank Code & $\begin{array}{c}\text { Larval } \\
\text { Development Time }\end{array}$ & $\begin{array}{c}\text { Pupal } \\
\text { Development Time }\end{array}$ & $\begin{array}{c}\text { Total } \\
\text { Development Time }\end{array}$ & $\begin{array}{c}\text { Early Stage Larval } \\
\text { Mortality (\%) }\end{array}$ \\
\hline VI033482 * & $13.43 \pm 0.30 a$ & $7.45 \pm 0.69 a$ & $20.00 \pm 0.8 \mathrm{a}$ & $8.0 \pm 3.27 \mathrm{bc}$ \\
\hline VI033479 & $13.24 \pm 0.23 a$ & $6.11 \pm 0.35 a$ & $18.67 \pm 0.44 a$ & $8.0 \pm 3.27 \mathrm{bc}$ \\
\hline VI036227 & NA & NA & NA & $100.0 \pm 0.0 \mathrm{a}$ \\
\hline VI044437-A & $13.29 \pm 0.29 a$ & $5.86 \pm 0.17 a$ & $18.82 \pm 0.28 \mathrm{a}$ & $14.0 \pm 5.21 b c$ \\
\hline VI049698 & $13.23 \pm 0.30 \mathrm{a}$ & $6.43 \pm 0.39 a$ & $19.24 \pm 0.36 a$ & $12.0 \pm 6.11 b c$ \\
\hline \multirow[t]{4}{*}{ VI056563 } & $14.00 \pm 0.56 a$ & $6.63 \pm 0.42 a$ & $19.75 \pm 0.53 a$ & $34.0 \pm 11.57 \mathrm{~b}$ \\
\hline & $\chi^{2}=1.066$ & $\chi^{2}=3.348$ & $x^{2}=1.042$ & $F=12.22$ \\
\hline & $\mathrm{df}=7,228$ & $\mathrm{df}=7,112$ & $\mathrm{df}=7,112$ & $\mathrm{df}=8,81$ \\
\hline & $p=0.994$ & $p=0.851$ & $p=0.994$ & $p<0.001$ \\
\hline
\end{tabular}

* Susceptible accession. Means followed by same lower-case letter within a column are not significantly different at $p<0.05$ (Tukey's test).

\subsection{Mortality Rates and Instantaneous Rate of Increase of S. recurvalis on Selected Amaranth Accessions}

Early stage larval mortality, within the first $36 \mathrm{~h}$, was observed in all the accessions with an overall mean mortality of $25.11 \pm 4.56 \%$ and ranged between $4.0 \pm 0.51$ and $100.0 \pm 0.0 \%$ across the accessions. There were significant differences $(F=12.22 ; \mathrm{df}=8,81 ; p<0.001)$ in early stage larval mortalities that occurred on the different accessions with VI036227 leading to significantly higher mortalities compared to all the other accessions including the susceptible accession (Table 4). The accession VI056563 led to significantly higher early stage mortality compared to RVI00053.The lowest early stage mortalities were recorded on accessions RVI00053, VI033479 and the susceptible check VI033482 (Table 4). The total larval mortalities across the different accessions ranged between $24.0 \pm 4.99 \%$ and $100 \pm 0.0 \%$ with an average of $47.56 \pm 3.19 \%$ (Figure 2). There were significant differences $(F=5.91 ; \mathrm{df}=8,81 ; p<0.001)$ in the larval mortalities when $S$. recurvalis was fed on different amaranth accessions. The accession VI036227 led to $100 \pm 0.0 \%$ larval mortality, which was significantly higher than larval mortality in all the other accessions except VI056563, which led to $64.00 \pm 9.8 \%$ larval mortality. The lowest larval mortality was recorded on accession RVI00053, which had a mean mortality of $24.0 \pm 4.99 \%$ (Figure 2). There was a significant negative linear correlation between the number of days before larval mortality occurred and the rate of larval mortality $(r=-0.428 ; p<0.001)$.

Pupal mortality also differed significantly $(F=2.92 ; \mathrm{df}=7,68 ; p=0.01)$ among the accessions tested. Accession VI044437-A had significantly lower pupal mortalities than RVI00053, VI033479 and the susceptible accession VI033482 (Figure 2). The average pupal mortality was $50.15 \pm 4.03 \%$. There was no correlation between larval and pupal mortalities $(r=0.064 ; p=0.58)$.

The instantaneous rate of increase $\left(r_{i}\right)$ when the larvae of $S$. recurvalis were exposed to the different amaranth accessions were negative (Figure 3 ). The $r_{i}$ also did not differ significantly among all the tested accessions. 


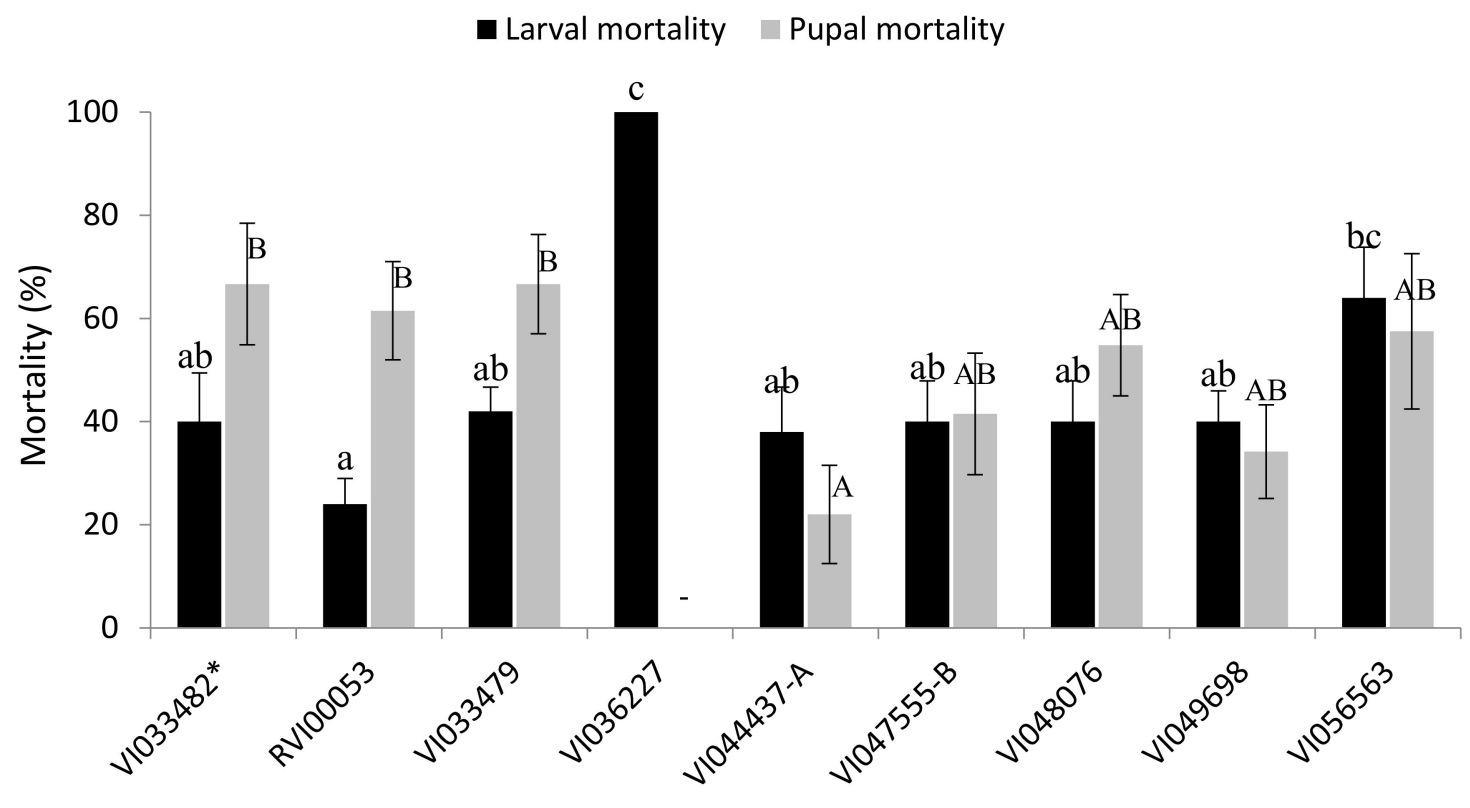

Amaranth accession

Figure 2. Total larval and pupal mortalities (mean $\pm \mathrm{SE}$ ) of $S$. recurvalis recorded on selected accessions of amaranth. (Means of total larval (pupal) mortality with the same lower (upper) case letters are not significantly different at $p<0.05$, (Tukey's test)). * Susceptible accession.

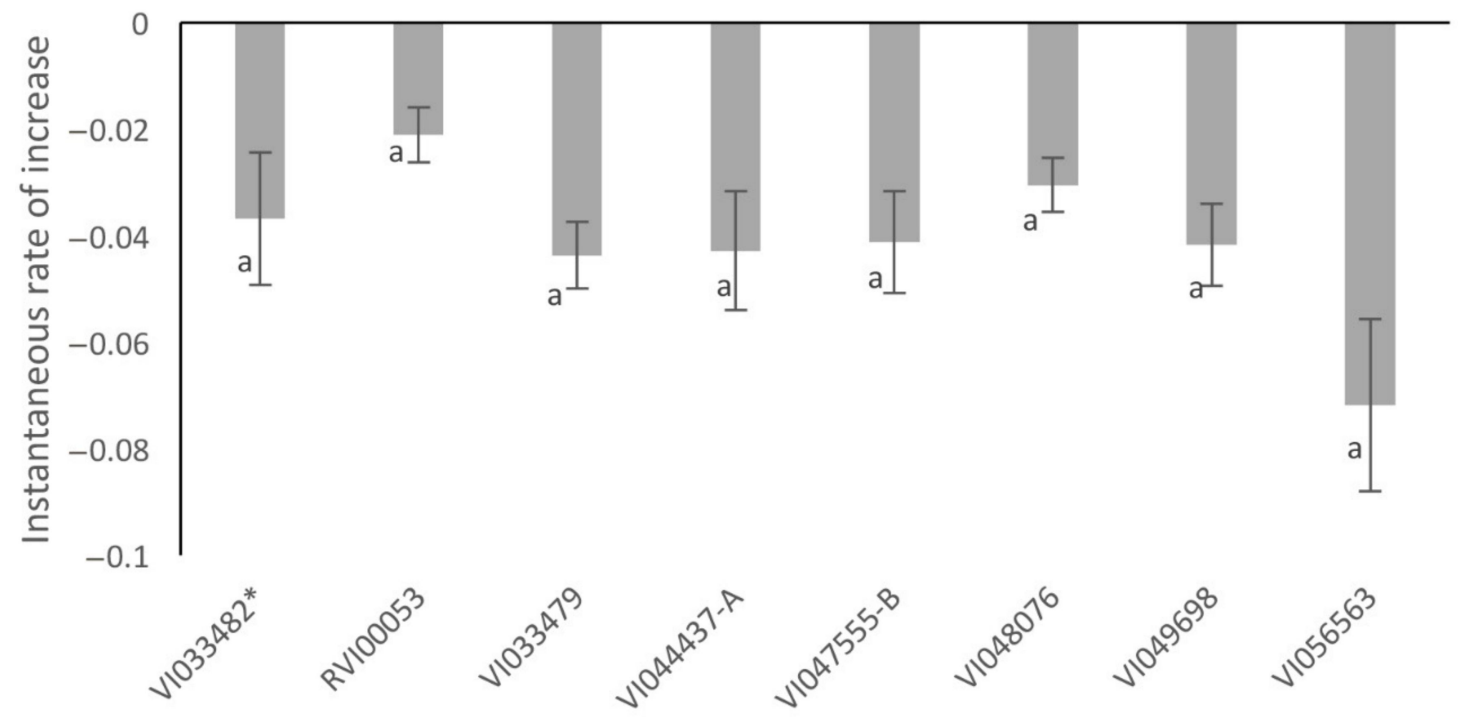

\section{Amaranth accession}

Figure 3. The mean instantaneous rate of population increase $\left(r_{i}\right)$ among larvae of Spoladea recurvalis when exposed to different amaranth accessions. Positive values of $r_{i}$ indicate a growing population, $r_{i}=0$ indicates a stable population, and negative $r_{i}$ values indicate a population in decline and headed toward extinction (Means with the same letter are not significantly different at $p<0.05$ (Tukey's test)). * Susceptible accession.

\subsection{Adult Longevity, Fecundity, Egg Viability and Sex Ratios of S. recurvalis}

There were significant differences in the adult longevity among the amaranth accessions $\left(\chi^{2}=92.51 ; \mathrm{df}=7,380 ; p<0.001\right)$ with accession VI047555-B producing adults with the shortest longevity $(8.7 \pm 0.61$ days), whereas adults from accession VI048076 had the longest longevity (14.25 \pm 0.82 days) (Table 5). Adults obtained from accessions VI056563 and VI048076 had significantly 
longer longevities compared to adults obtained from the susceptible accession VI033482 and the accessions VI047555-B, VI044437-A and VI033479. Accession VI047555-B also produced adults that had a shorter longevity compared to those from accessions VI044437-A, VI033479, RVI00053, and VI049698 (Table 5). The viability of eggs laid by $F_{1}$ females of $S$. recurvalis that were reared on the different amaranth accessions did not differ significantly $(F=0.89 ; \mathrm{df}=7,32 ; p=0.527)$ (Table 5$)$. Fecundity of the $\mathrm{F}_{1}$ females obtained from the various amaranth accessions differed significantly $(F=6.07 ; \mathrm{df}=7,14$; $p=0.002$ ) with accessions VI049698 and the susceptible accession VI033482 leading to the production of more eggs compared to accessions VI033479, VI044437-A and VI048076 (Table 5). There was no significant difference $(F=0.74 ; \mathrm{df}=7,25 ; p=0.638)$ in the proportions of $F_{1}$ females obtained from the amaranth accessions tested (Table 5).

Table 5. Spoladea recurvalis adult longevity, egg viability (\%), fecundity and proportion of $\mathrm{F}_{1}$ females (mean $\pm \mathrm{SE}$ ) on selected amaranth accessions.

\begin{tabular}{cccccc}
\hline Gene Bank Code & $\begin{array}{c}\text { Adult Longevity } \\
\text { (Days) }\end{array}$ & Odds Ratio & Egg Viability (\%) & $\begin{array}{c}\text { Fecundity/Female } \\
\text { at 4-d-old }\end{array}$ & $\begin{array}{c}\text { Proportion of } \\
\text { Females (\%) }\end{array}$ \\
\hline VI047555-B & $8.70 \pm 0.61 \mathrm{a}$ & 0.9 & $91.25 \pm 1.93 \mathrm{a}$ & $13.06 \pm 1.20 \mathrm{ab}$ & $51.79 \pm 7.03 \mathrm{a}$ \\
VI033482 & $9.69 \pm 0.85 \mathrm{ab}$ & & $95.49 \pm 1.50 \mathrm{a}$ & $22.67 \pm 3.67 \mathrm{a}$ & $59.17 \pm 8.86 \mathrm{a}$ \\
VI044437-A & $10.85 \pm 0.52 \mathrm{~b}$ & 1.12 & $97.79 \pm 3.13 \mathrm{a}$ & $11.09 \pm 0.80 \mathrm{~b}$ & $44.97 \pm 8.01 \mathrm{a}$ \\
VI033479 & $10.85 \pm 0.85 \mathrm{~b}$ & 1.12 & $97.62 \pm 1.61 \mathrm{a}$ & $10.97 \pm 1.71 \mathrm{~b}$ & $45.49 \pm 4.51 \mathrm{a}$ \\
RVI00053 & $11.00 \pm 0.79 \mathrm{bc}$ & 1.14 & $97.53 \pm 1.51 \mathrm{a}$ & $13.40 \pm 1.74 \mathrm{ab}$ & $66.91 \pm 8.09 \mathrm{a}$ \\
VI049698 & $11.22 \pm 0.49 \mathrm{bc}$ & 1.16 & $96.25 \pm 2.33 \mathrm{a}$ & $23.75 \pm 3.50 \mathrm{a}$ & $46.03 \pm 6.31 \mathrm{a}$ \\
VI056563 & $12.63 \pm 0.82 \mathrm{~cd}$ & 1.3 & $95.90 \pm 4.10 \mathrm{a}$ & $14.67 \pm 5.67 \mathrm{ab}$ & $49.77 \pm 5.83 \mathrm{a}$ \\
VI048076 & $14.25 \pm 0.82 \mathrm{~d}$ & 1.47 & $94.66 \pm 2.59 \mathrm{a}$ & $8.50 \pm 0.74 \mathrm{~b}$ & $56.76 \pm 13.44 \mathrm{a}$ \\
& $p<0.001$ & & $p=0.527$ & $p=0.002$ & $p=0.638$ \\
& $\mathrm{df}=7,380$ & & $\mathrm{df}=7,32$ & $\mathrm{df}=7,14$ & $\mathrm{df}=7,25$ \\
& $\chi^{2}=92.51$ & & $F=0.89$ & $F=6.07$ & $F=0.74$ \\
\hline
\end{tabular}

* Susceptible accession. Means followed by the same lower-case letter within a column are not significantly different at $p<0.05$ (Tukey's test).

\section{Discussion}

Amaranth accessions possessed different morphological and physical characteristics such as leaf coloration, shape and sizes. The accession VI036227 had significantly smaller leaves compared to the susceptible accession while accessions VI046233-A, VI033477 and VI056563 had red leaves compared to the green leaves of the susceptible accession. Pest preference for a plant variety has been attributed to the plants' physical, morphological and chemical features [32-35]. Physical features like petiole length, breadth of leaf, pigmentation and presence of trichomes have been reported to affect insect pest preference in several crops including amaranths [34,36,37]. Hillier et al. [38] also related pest abundance to the density of plant foliage. In addition, morphological characteristics play an important role in determining farmer and consumer preferences for a variety over others [3]. Therefore, whereas accession VI036227 exhibited high resistance, the tiny leaves it possesses may be a hindrance for its acceptance in certain regions. Similarly, the red coloration of accession VI056563 may inhibit its acceptability certain regions. Further studies are recommended to assess consumer and farmer preferences for selected resistant amaranth accessions.

When offered a choice of hosts for oviposition, S. recurvalis exhibited varying levels of preference for the different accessions for oviposition. The accessions VI050609-B and VI048919 did not show antixenosis for oviposition as they had significantly higher number of eggs compared to the susceptible control VI033482. Several accessions (32 out of the 35 tested) exhibited oviposition deterrence, having $<50 \%$ of eggs recorded in the susceptible control. Accessions VI044432, VI049502 and VI054569 exhibited high levels of antixenosis with $<2$ eggs compared to 21 eggs in the susceptible control. The choice by an insect to oviposit on a particular plant host and not on the other is usually determined by factors such as plant volatiles, plant anatomy, host nutrition, mobility of immatures, presence of natural enemies and competitors, among others [39]. In the case of S. recurvalis on the different accessions of amaranth, it is still premature to predict with certainty which one of these factors played a significant role in 
antixenosis, but we predict that plant volatiles might be of the most importance. Further research is therefore recommended to determine which of these factors are key in the expression of antixenosis against $S$. recurvalis.

Spoladea recurvalis was observed to lay more eggs on the susceptible accession in no choice conditions compared to the selected resistant accessions. This further reiterates the expression of antixenosis for oviposition at varying levels against $S$. recurvalis in these resistant accessions with VI048076 having reduced number of eggs. Significantly fewer eggs were also laid per female in the choice than the no-choice conditions on all the accessions. According to Grovida [24], S. recurvalis is largely restricted to plants in the family Amaranthaceae and can be said to be a specialist. In seeking oviposition sites, specialists are usually under pressure to find suitable hosts and prioritize hosts that will offer quality nutrition for their offspring $[39,40]$. There is, therefore, a likely trade-off by $S$. recurvalis between the number of eggs and time spent by the female in seeking for a suitable host in the choice conditions compared to no-choice situations. In addition, competition between the female conspecifics for suitable host in the choice assay may also lead to reduced number of eggs. Thus, in practice, it would be more beneficial for a farmer to grow more than one variety/line/species of amaranth in a mixed cropping system so as to reduce the pest burden or to interplant susceptible varieties, or avoid monocultures altogether.

Larval, pupal and total developmental time did not differ significantly among the tested accessions where development was successfully completed. This is probably due to similarity in the nutrient composition and quantities or composition of secondary compounds among the amaranth accessions [41]. Shorter developmental time of an insect pest on a host is usually an indicator of a more suitable host crop [41]. Jeyasankar and Gokilamani [4] reported mean larval, pupal and total development times of S. recurvalis to be $13 \pm 3.0,10 \pm 2.0$ and $25.5 \pm 5.5$ days, respectively on an amaranth variety, which is similar to our values of $13.5 \pm 0.12,6.36 \pm 0.13$ and $19.09 \pm 0.15$ days for larval, pupal and total developmental times, respectively. Similar developmental times of $S$. recurvalis were also recorded by Seham et al. [42] on sugar beet and Bhattacherjee and Ramdas-Menon [43] on an unknown plant species at $25 \pm 2{ }^{\circ} \mathrm{C}$. The slight variations in the developmental times of $S$. recurvalis may be due to differences in experimental conditions and host plants used or to differences in populations of $S$. recurvalis.

A high level of resistance was observed on accession VI036227 on which larval development of $S$. recurvalis could not proceed beyond the first instar. This could be a result of expression of antixenosis by the accession in which the plant produces feeding deterrents (volatiles) that prevent the larvae of $S$. recurvalis from feeding and resulting in death due to starvation. There is also a possibility of antibiosis where the plant possesses highly potent secondary metabolites that kill the pest larvae upon feeding on it. Secondary metabolites belonging to the group of phenolic acids were shown to have negative effects on insects by acting as deterrents or being toxic to non-adapted insects by inducing toxic oxidative stress on herbivores $[7,44,45]$. Hence, further studies are recommended to elucidate the bases of resistance of this accession in comparison with other resistant accessions with a special focus on the analysis of secondary metabolites and their role in pest resistance.

Larval mortality was highest on accession VI036227 (100\%) and higher on accession VI056563 compared to RVI00053. High larval mortality on accession VI056563 is therefore an indication that it is unsuitable for the development of $S$. recurvalis in comparison to RVI00053. Negative $r_{i}$ values on all the accessions also indicate a decline in larval populations on these accessions. High larval mortality rates could be due to sub-optimal nutritional quality in the accession or presence of secondary metabolites that do not promote development of $S$. recurvalis. Early stage larval mortality was highest on accession VI036227 followed by VI056563 and was least on RVI00053. Voracious feeding by larvae of $S$. recurvalis usually begins after the second instar, when larvae can feed on entire foliage leaving only leaf veins intact $[12,21,24]$. Low mortality rates during the early stages of larval development would therefore result in greater damage inflicted on the plant as the larvae grow and feed. High early stage larval mortalities as observed on accession VI036227 is of critical importance and very desirable in the selection of resistant accessions because negligible damage is caused by larvae at this stage. 
Nevertheless, there was no significant difference in oviposition choice between this accession and the susceptible one, making it a 'dead-end' trap crop for S. recurvalis. On the contrary, accessions RVI00053, VI033479 and the susceptible check VI033482, which had low early stage mortalities, provide increased opportunities for the pest to cause extensive foliage damage as it matures. Pupal mortalities were higher on accessions RVI00053 and VI033479 compared to VI044437-A and were not correlated to larval mortalities suggesting that different compounds are responsible for mortality in the larvae and pupae of $S$. recurvalis. High larval and pupal mortalities have a significant role in reducing the populations of the pest in the subsequent generations and therefore accessions that lead to greater mortalities are highly desirable.

Apart from accession VI036227, which led to a significantly low weight gain when larvae of $S$. recurvalis were fed on it, weight gain from the other accessions did not differ significantly. The minimal weight gain on accession VI036227 (7.57\% compared to $>120 \%$ in other accessions) further reiterates the presence of either a feeding deterrent or a highly toxic secondary metabolite against larvae of S. recurvalis. Weight gain in the remaining accessions did not differ significantly, indicating that feeding by $S$. recurvalis larvae on the accessions was not deterred and suggests a lack of antixenosis for feeding in the accessions.

Significant differences in the longevity of adults of $S$. recurvalis raised on the different accessions were noted in our study, with accession VI047555-B producing adults with the shortest longevity. Shortened adult longevity is usually an indication of a less suitable host plant and is mainly attributed to low nutritional quality of that host plant [46]. Differences in the adult longevity of S. recurvalis were also reported between Trianthema portulacastrum L. (5.68 \pm 0.7 days) and Amaranthus sp. (4.99 \pm 0.3 days) [47] in Taiwan. Pande [48] also reported short adult longevities of between 3.5 and 6 days in males and females, respectively on Trianthema monogyna L. In contrast, Shirai [49] reported extended adult longevities of $18.8 \pm 7.6$ days and $15.1 \pm 6.9$ days in females and males of $S$. recurvalis, respectively when fed on spinach leaves (Spinacia oleracea L.) and Seham et al. [42] reported longevities of $28.46 \pm 1.88$ and $26.08 \pm 1.83$ in females and males of $S$. recurvalis, respectively, when fed on sugar beet (Beta vulgaris L.). Although this broad variation in S. recurvalis adult longevities can be due to the differences in experimental conditions as in Seham et al. [42] at $18.6 \pm 2{ }^{\circ} \mathrm{C}$ and $70 \pm 5 \% \mathrm{RH}$, the host plant on which the pest develops could play a big role [47]. Other studies involving lepidopteran pests when reared on different host plants including Helicoverpa armigera Hübner [46] have also shown differences in adult longevity. Thus, shortened adult longevity can be attributed to expression of antibiosis by the host plant or inadequate nutrition in the host plant.

The accession VI036227 exhibited exemplary antibiotic traits by causing $100 \%$ pest mortality. However, it possessed very undesirable morphological/agronomic traits mainly tiny leaves (more than 6 times smaller than susceptible check), slow germination and prostate growth habit. In East Africa, vegetable leaf yield is of high importance to both farmers and breeders [3], posing the challenge of acceptability to this resistant accession by farmers and consumers. The other seven accessions had traits such as moderate mortality rates on accession VI056563 and elicited lower rates of oviposition compared to the susceptible check. They also possess better morphological/agronomic traits compared to VI036227, including erect growth habit and large/broad leaves, which may result in high vegetable leaf yields and might easily be accepted by local farmers and breeders. Whether the desirable antibiotic trait of accession VI036227 can be transferred to confer resistance to locally cultivated varieties and other accessions of amaranth is still unclear and is strongly recommended for future studies. Further studies are also recommended to assess farmers' and consumers' preferences and acceptance/willingness to cultivate and consume these pest resistant accessions. The yield potential, storability, drought tolerance and nutritive attributes of these different resistant varieties under various agro-ecological conditions also warrant further research. 


\section{Conclusions}

The assessed amaranth accessions expressed both antixenotic and antibiotic resistance traits against S. recurvalis. Antixenosis traits exhibited through non-preference for oviposition were highly expressed in several accessions including VI044432, VI049502, VI054569 and VI048076. Larval development was completely hindered on accession VI036227, resulting in 100\% larval mortality and points to presence of potent antibiosis. In addition, VI036227 showed no antixenosis, suggesting further potential as a 'dead-end' trap crop. Early stage larval mortality, total larval and pupal mortalities as well as adult longevity were moderate on accessions VI048076, VI056563 and VI047555-B suggesting moderate level of antibiosis. HPR to insect pests forms the core of many IPM programs [50,51] but is seldom exploited for pest management among TLVs. This is despite the fact that HPR is not only compatible with environmental concerns and other pest management strategies, but also significantly reduces pest control expenses [46], since the pest management solution is inherent in the crop. The accessions expressing adverse effects on the biology of $S$. recurvalis are thus recommended for evaluation for an IPM package for the management of the pest.

Author Contributions: S.T.O.O., S.R., R.K., T.D., S.E. and K.K.M.F. conceived and designed the experiments; S.T.O.O. performed the experiments; S.T.O.O. analysed the data; S.R., T.D., S.E. and K.K.M.F. contributed reagents/materials/analysis tools; S.T.O.O., S.R., R.K., T.D., S.E. and K.K.M.F. wrote the paper; S.R. and K.K.M.F secured funding.

Funding: Bundesministerium für Wirtschaftliche Zusammenarbeit und Entwicklung: 13.1432.7-001.00.

Acknowledgments: We acknowledge UK Aid from the UK Government; the Swedish International Development Cooperation Agency (SIDA); the Swiss Agency for Development and Cooperation (SDC), and the Kenyan Government for their financial support to research agenda of icipe. The first author received a scholarship in the BMZ-funded project through the Dissertation of Research Internship Program (DRIP) of icipe. The authors also express their gratitude to the project team for their technical assistance and to WorldVeg for allowing the field trials to be conducted at their institution.

Conflicts of Interest: The authors declare no conflict of interest.

\section{References}

1. Amicarelli, V.; Camaggio, G. Amaranthus: A crop to rediscover. Forum Ware Int. 2012, 2, 4-11.

2. Ezeh, A.; Ogedegbe, A.; Ogedegbe, S. Insect pest occurrence on cultivated Amaranthus spp. in Benin city, Edo state, Nigeria. J. Appl. Sci. Environ. Manag. 2015, 19, 335-339. [CrossRef]

3. Dinssa, F.; Hanson, P.; Dubois, T.; Tenkouano, A.; Stoilova, T.; Hughes, J.; Keating, J. AVRDC-The world vegetable center's women-oriented improvement and development strategy for traditional African vegetables in sub-saharan Africa. Eur. J. Hortic. Sci. 2016, 81, 91-105. [CrossRef]

4. Jeyasankar, A.; Gokilamani, D. Biology and eco-friendly control of amaranths pests, Hymenia recurvalis Fabricius and Psara basalis Walker (Lepidoptera: Crambidae). Int. J. Acad. Stud. 2016, 2, 218-230.

5. Adebooye, O.; Opabode, J. Status of conservation of the indigenous leaf vegetables and fruits of Africa. Afr. J. Biotechnol. 2004, 3, 700-705.

6. Costea, M.; Weaver, S.E.; Tardif, F.J. The biology of Canadian weeds. 130. Amaranthus retroflexus L., A. powellii S. Watson and A. hybridus L. Can. J. Plant Sci. 2004, 84, 631-668. [CrossRef]

7. Niveyro, S.L.; Mortensen, A.G.; Fomsgaard, I.S.; Salvo, A. Differences among five amaranth varieties (Amaranthus spp.) regarding secondary metabolites and foliar herbivory by chewing insects in the field. Arthropod-Plant Interact. 2013, 7, 235-245. [CrossRef]

8. Ouma, M. Indigenous Vegetable Production and Utilization in Suba District, Kenya: Improving Health, Unlocking the Wealth in Suba District. Bio Vision-TTU, ICIPE 2004. Available online: http://www. infonet-biovision.org/sites/default/files/indigenous_veg_production_suba_district_ouma.pdf (accessed on 5 January 2018).

9. Gikonyo, N.; Mburu, M.; Kenji, G.; Mwasaru, A. Properties of a complementary food based on amaranth grain (Amaranthus cruentus) grown in Kenya. J. Agric. Food Tech. 2011, 1, 153-178. 
10. Liu, F.; Stützel, H. Leaf expansion, stomatal conductance, and transpiration of vegetable amaranth (Amaranthus sp.) in response to soil drying. J. Am. Soc. Hortic. Sci. 2002, 127, 878-883.

11. Aderolu, I.; Omooloye, A.; Okelana, F. Occurrence, abundance and control of the major insect pests associated with amaranths in Ibadan, Nigeria. Entomol. Ornithol. Herpetol. 2013, 2, 112. [CrossRef]

12. James, B.; Atcha-Ahowé, C.; Godonou, I.; Baimey, H.; Goergen, H.; Sikirou, R.; Toko, M. Integrated Pest Management in Vegetable Production: A Guide for Extension Workers in West Africa; IITA: Ibadan, Nigeria, 2010.

13. Kagali, R.N.; Kioko, E.N.; Osiemo, Z.; Muya, S.; Wachera, C. Insect abundance and diversity on cultivated Amaranthus spp. (amaranthacea) in Meru county, Kenya. Am. Int. J. Contemp. Res. 2013, 3, 110-116.

14. Mureithi, D.; Mworia, J.; Meyhöfer, R.; Murungi, L.; Losenge, T.; Akutse, K.; Ekesi, S.; Fiaboe, K. Survey for pest and natural enemies of amaranth and African nightshades in Kenya and Tanzania. In Proceedings of the TROPENTAG 2015, Humboldt-Universität, Berlin, Germany, 16-18 September 2015.

15. Sharma, G.; Ramamurthy, V. A Checklist of Lepidopterous Pests of Vegetables in INDIA. 2009. Available online: www.zsi.gov.in/zoological-survey-of-india/zsi-data/checklist/index.htm (accessed on 1 February 2018).

16. Clarke-Harris, D.; Fleischer, S.; Fuller, C.; Bolton, J. Evaluation of the efficacy of new chemistries for controlling major Lepidoptera pests on vegetable amaranth in Jamaica. CARDI Rev. 2004, 4, 12-19.

17. García, A.A.; Huato, M.Á.D.; Lara, M.H.; Sáenz-de-Cabezón, F.J.; Pérez-Moreno, I.; Marco-Mancebón, V.; López-Olguín, J.F. Insect occurrence and losses due to phytophagous species in the amaranth Amaranthus hypocondriacus L. crop in Puebla, Mexico. Afr. J. Agric. Res. 2011, 6, 5924-5929.

18. Niveyro, S.; Salvo, A. Taxonomic and functional structure of phytophagous insect communities associated with grain amaranth. Neotrop. Entomol. 2014, 43, 532-540. [CrossRef] [PubMed]

19. Batra, H.; Bhattacherjee, N. Occurrence of Hymenia recurvalis (Fabricius) (Lepidoptera: Pyalidae) as a bad pest of some leaf vegetables. Indian J. Entomol. 1960, 22, 128-130.

20. Mureithi, D.M.; Komi, F.K.; Ekesi, S.; Meyhöfer, R. Important arthropod pests on leafy amaranth (Amaranthus viridis, A. tricolor and A. blitum) and broad-leafed African nightshade (Solanum scabrum) with a special focus on host-plant ranges. Afr. J. Hortic. Sci. 2017, 11, 1-17.

21. Othim, S.; Agbodzavu, K.; Kahuthia-Gathu, R.; Akutse, K.; Muchemi, S.; Ekesi, S.; Fiaboe, K. Performance of Apanteles hemara (Hymenoptera: Braconidae) on two amaranth leaf-webbers: Spoladea recurvalis and Udea ferrugalis (Lepidoptera: Crambidae). Environ. Entomol. 2017, 46, 1284-1291. [CrossRef] [PubMed]

22. Othim, S.T.; Kahuthia-Gathu, R.; Akutse, K.; Foba, C.; Fiaboe, K. Seasonal occurrence of amaranth lepidopteran defoliators and effect of attractants and amaranth lines in their management. J. Appl. Entomol. 2018. [CrossRef]

23. Clarke-Harris, D.; Fleischer, S.; Fender, A. Major pests of callaloo. In Identification Guide; The Pennsylvania State University: State College, PA, USA, 1998.

24. Grovida, F. Vegetable Pests. 2015. Available online: http:/ /www.grovida.us/vegetable-pests.html (accessed on 26 May 2015).

25. Arivudainambi, S.; Selvamuthukumaran, T.; Baskaran, P. Efficacy of herbal extracts in management of amaranth leaf caterpillar. Int. J. Veg. Sci. 2010, 16, 167-173. [CrossRef]

26. Chahal, K.; Singh, B.; Kang, B.; Battu, R.; Joia, B. Insecticide residues in farmgate vegetable samples in Punjab. Pestic. Res. J. 1997, 9, 256-260.

27. Gitonga, Z.M.; Chabi-Olaye, A.; Mithöfer, D.; Okello, J.J.; Ritho, C.N. Control of invasive Liriomyza leafminer species and compliance with food safety standards by small scale snow pea farmers in Kenya. Crop Prot. 2010, 29, 1472-1477. [CrossRef]

28. Srinivasan, R. Integrating biopesticides in pest management strategies for tropical vegetable production. J. Biopestic. 2012, 5, 36-45.

29. Landolt, P.; Jang, E.; Carvalho, L.; Pogue, M. Attraction of pest moths (Lepidoptera: Noctuidae, Crambidae) to floral lures on the island of hawaii. Proc. Hawaii. Entomol. Soc. 2011, 43, 49-58.

30. Othim, S.T.; Srinivasan, R.; Kahuthia-Gathu, R.; Dubois, T.; Dinssa, F.; Ekesi, S.; Fiaboe, K. Screening for pest resistance against important lepidopteran and stem weevil pests attacking amaranth in Tanzania. Euphytica 2018. under review.

31. Stark, J.D.; Banks, J.E. Population-level effects of pesticides and other toxicants on arthropods. Ann. Rev. Entomol. 2003, 48, 505-519. [CrossRef] [PubMed]

32. Gatehouse, J.A. Plant resistance towards insect herbivores: A dynamic interaction. New Phytol. 2002, 156, $145-169$. [CrossRef] 
33. Kumar, S.; Atri, C.; Sangha, M.K.; Banga, S. Screening of wild crucifers for resistance to mustard aphid, lipaphis erysimi (kaltenbach) and attempt at introgression of resistance gene (s) from Brassica fruticulosa to Brassica juncea. Euphytica 2011, 179, 461-470. [CrossRef]

34. Akaneme, F.; Ani, G. Morphological assessment of genetic variability among accessions of amaranthus hybridus. World Appl. Sci. J. 2013, 28, 568-577.

35. Jared, J.J.; Murungi, L.K.; Wesonga, J.; Torto, B. Steroidal glycoalkaloids: Chemical defence of edible african nightshades against the tomato red spider mite, tetranychus evansi (acari: Tetranychidae). Pest Manag. Sci. 2016, 72, 828-836. [CrossRef] [PubMed]

36. Jiang, C.-X.; Wright, R.; Woo, S.; DelMonte, T.; Paterson, A. Qtl analysis of leaf morphology in tetraploid gossypium (cotton). Theor. Appl. Genet. 2000, 100, 409-418. [CrossRef]

37. War, A.R.; Paulraj, M.G.; Ahmad, T.; Buhroo, A.A.; Hussain, B.; Ignacimuthu, S.; Sharma, H.C. Mechanisms of plant defense against insect herbivores. Plant Signal. Behav. 2012, 7, 1306-1320. [CrossRef] [PubMed]

38. Hillier, N.; Dixon, P.; Larson, D. Trap captures of male grapholita libertina (lepidoptera: Tortricidae) moths: Relationship to larval numbers and damage in wild lingonberry1. Environ. Entomol. 2004, 33, 405-417. [CrossRef]

39. Martínez, G.; Soler, R.; Dicke, M. Behavioral ecology of oviposition-site selection in herbivorous true bugs. In Advances in the Study of Behavior, 1st ed.; Jane-Brockmann, H., Roper, T.J., Naguib, M., Barrett, L., Eds.; Elsevier: New York, NY, USA, 2013; Volume 45, pp. 175-207. ISBN 9780124071865.

40. Jaenike, J. Host specialization in phytophagous insects. Annu. Rev. Ecol. Syst. 1990, 21, 243-273. [CrossRef]

41. Mardani-Talaei, M.; Nouri-Ganbalani, G.; Naseri, B.; Hassanpour, M. Life history studies of the beet armyworm, Spodoptera exigua (Hübner) (Lepidoptera: Noctuidae) on 10 corn hybrids. J. Entomol. Res. Soc. 2012, 14, 9-18.

42. Seham, S.; Mostafa, F.; Aly, F.; Hussein, S. Certain biological aspects, threshold of development and thermal units for Hymenia recurvalis (Fab.), (Lepidoptera: Pyrallidae). Arab Univ. J. Agric. Sci. 2006, 14, 447-456.

43. Bhattacherjee, N.; Ramdas, M. Bionomics, biology and control of Hymenia recurvalis (Fabricius)(Pyralidae: Lepidoptera). Indian J. Entomol. 1964, 26, 176-183.

44. Simmonds, M.S. Flavonoid-insect interactions: Recent advances in our knowledge. Phytochemistry 2003, 64, 21-30. [CrossRef]

45. Summers, C.B.; Felton, G.W. Prooxidant effects of phenolic acids on the generalist herbivore Helicoverpa zea (Lepidoptera: Noctuidae): Potential mode of action for phenolic compounds in plant anti-herbivore chemistry. Insect Biochem. Mol. Biol. 1994, 24, 943-953. [CrossRef]

46. Liu, Z.; Li, D.; Gong, P.; Wu, K. Life table studies of the cotton bollworm, Helicoverpa armigera (Hübner)(Lepidoptera: Noctuidae), on different host plants. Environ. Entomol. 2004, 33, 1570-1576. [CrossRef]

47. Hsu, Y.-C.; Srinivasan, R. Desert horse purslane weed as an alternative host for amaranth leaf webber, Hymenia recurvalis in Taiwan. Formos. Entomol. 2012, 32, 297-302.

48. Pande, Y. Some observations on the bionomics of Hymenia recurvalis F. (Lepid., Pyralidae) feeding on Trianthema monogyna and Amaranthus viridis in India. J. Appl. Entomol. 1972, 72, 362-366. [CrossRef]

49. Shirai, Y. Flight activity, reproduction, and adult nutrition of the beet webworm, Spoladea recurvalis (Lepidoptera: Pyralidae). Appl. Entomol. Zool. 2006, 41, 405-414. [CrossRef]

50. Cortesero, A.; Stapel, J.; Lewis, W. Understanding and manipulating plant attributes to enhance biological control. Biol. Control 2000, 17, 35-49. [CrossRef]

51. Pappas, M.L.; Broekgaarden, C.; Broufas, G.D.; Kant, M.R.; Messelink, G.J.; Steppuhn, A.; Wäckers, F.; van Dam, N.M. Induced plant defences in biological control of arthropod pests: A double-edged sword. Pest Manag. Sci. 2017, 73, 1780-1788. [CrossRef] [PubMed]

(C) 2018 by the authors. Licensee MDPI, Basel, Switzerland. This article is an open access article distributed under the terms and conditions of the Creative Commons Attribution (CC BY) license (http:/ / creativecommons.org/licenses/by/4.0/). 